\title{
Carton Dosing Unit
}

National Cancer Institute

\section{Source}

National Cancer Institute. Carton Dosing Unit. NCI Thesaurus. Code C54702.

A dosing unit equal to the amount of active ingredient(s) contained in a carton. 